\title{
Creative Cultural Industries: A Great Economic Capital for the Social, Political and Economic Development of Africa
}

\author{
Sara Larson and Andien Hugo
}

\begin{abstract}
The cultural and artistic productions of Africa have various dimensions that emphasize the pivotal role art plays in the development of societies. This justifies why art and societal living and progression are intertwined. This article explains the influence of art in the social, political, and economic development in African societies. African art is related to the development of the total life of Africans. This includes the dressing styles, eating habits, values and the norms in the African society. It also embraces the use of art and our cultural heritage in addressing the social problems faced by the ethnic societies in the African continent. Many modern societies in Africa are faced with the challenge of teenage pregnancy, environmental pollution and other forms of social vices. Strategies and solutions to these staggering problems can be found in the sound values, norms, belief systems and practices in Africa. For instance, many scholars in African studies and cultures are calling for a re-visitation and revival of the indigenous practices of initiation rites for the youth that ensured that moral chasteness was maintained by the youth, including the abstinence from pre-marital sex and all other forms of social vices associated with the youth today. It was the measure put in place by the elderly members of the societies in introducing the mantle of leadership to the youth. The initiation rites were platforms for keeping the youth abreast with their social duties as responsible adults.
\end{abstract}

Keyword: Economic Development, Creative Cultural Industries, Indigenous Societies, Africa.

\section{INTRODUCTION}

In addition, the African cosmological belief systems also call for living in harmony with nature while sustainable using nature's resources. Finding ways of implementing these precepts in modern African societies could bolster their social development. Moreover, African art and culture unearth the language diversities of Africa. It traces the historical development of languages, which is the first step in understanding the cultures of a people. The study of the various forms of art, including the attire, colour choice, design elements, shapes and so forth, helps in understanding the social classes and personalities in the African society. 
Politically, African art and culture play quintessential roles in the political lives of the African people. The political artefacts serve as a means of identifying and defining the political roles of rulers such as traditional chiefs, spokespersons, traditional priests and so forth. The political arts empower the ruling class in Africa in performing their priestly duties; exercise their administrative, executive, judicial and military duties.

Economically, the various forms of African art improve the standard of living of the African people. The production and use of the arts satisfy the needs of the people in the society either directly or indirectly. The direct means of producing the artworks in addressing the needs of the people are through the selling of the art pieces and the use of them in carrying out their daily activities. It also involves the use of art forms as incentives for increasing the production of other goods and services in the community to improve the general well being of the people. The study of African art and culture highlights the role of art in providing vocations and job avenues for the members of the society.

These vocations in the arts will equip the youth with food providing pursuit skills so that they will have a means of livelihood for themselves and their families. The great wealth from artworks is an asset for the society. In times of economic strains, the artworks can be sold to improve the conditions of living of the people. Court artists who produce the general regalia of the state such as stools, palanquins, spokesmen staff, textiles and others generate economic revenue from them. Counterfeit copies of some of the chief's regalia are produced as souvenir items and exchanged for foreign currencies. During festivals and other cultural events in Africa, these regalia souvenir items are sold to the general public, especially tourists, generating monetary revenue. This greatly improves the tourism industry of countries in Africa.

\section{DISSCUSION}

\section{Creative Cultural Industries: A Great Economic Capital For Indigenous Societies}

Almost every indigenous society had a unique artistic production that is native to the people. These cultural artifacts are creatively fashioned from local materials that are readily available in the indigenous communities' environments. They were the chief professions of the creative forebears of old that served as the pivot for their economies. In fact, those artifacts that they produced were their sole means of economic capital used for tending for families and developing the ancient societies. 
These creative cultural artifacts have been great parting treasures from the ancestors of numerous local communities to their present and future progeny. The creative cultural artistic industry is a potential economy of contemporary societies that settle on the soils of these indigenous societies. It can be a strategic tool for alleviating the impoverished state of the local residents in those communities.

It is true that the cultural and creative arts industries are potential economic boosting ventures in this contemporary age. It is one of the ever thriving areas of the global economy with an estimated growth rate of $4.3 \%$ in North and Central America, 6.9\% in Oceania, 9.7\% in Asia, $11.9 \%$ in South America, $13.9 \%$ in Africa and $17.6 \%$ in the Middle East. These estimates that show a soaring increase in global economy clearly underscores the great economic capital that can be obtained from the creative cultural industries from our forebears! Thus, today, local communities, especially the women and the youth who are mostly unemployed must tap into these industries to earn a living. It is not very difficult for residents to enter into these industries.

Limited capital investment is often required to start an enterprise in the creative and cultural industry of local communities. This is because the raw materials for the production of the creative cultural artifacts are locally stepped in the regions of the local communities' territories. Usually, the local governments and the traditional authorities have their own effective managerial ways of ensuring the sustainable supply of these local resources for the artistic production. Individual families mostly have their family farms where the raw materials for the cultural artifacts are grown. Thus, it does not require huge capital to acquire the local materials for the artistic production.

Moreover, the local skills and expertise for the artistic productions are normally passed on from parents to children as part of the family's great possessions. Thus, children grow up learning the skills of production from the old sages in the society. Thus, endowed with the expertise, skills, and knowledge, it makes it quite easy for the vulnerable population such as elderly women and the youth to enter into these cultural and creative industries to earn a living.

Also, there is often a ready market for these cultural artifacts since it is mostly the preserve of these local communities. Many tourists and traders usually parade to these indigenous societies to purchase their unique cultural artifacts that portray the culture of the people. For instance, the Ntonso, Adanwumase and Bonwire indigenous societies in the Ashanti region of Ghana noted for the production of the indigenous clothes, Kente, Kuntunkuni, Adinkra, and Kobene receive thousands of tourists from various foreign countries who patronize the 
buying of these cultural artifacts. Such is the case of other unique creative cultural artifacts native to the other indigenous societies across the globe.

However, it is sad that most youths shun enrollment into these local industries for employment. Some of these youngsters prefer white-colored jobs which often leave them in the lurk, handicapped in employment. These youngsters fail to appreciate and recognize the economic potentials of these ready-made industries! They must be coached and enlightened to realize the wisdom in humbly enrolling in this great revenue generating ventures left to them by their industrious forebears. Non-governmental organizations in charge of entrepreneurship counseling and training must rigorously engage in educating young ones and other members in these indigenous societies on the economic wealth and simple ways of setting up small-scale industries via these creative cultural artifacts.

In addition, financial institutions and credit agencies must be ready to offer these local residents soft loans to start-up the establishment of small industries in this income generating cultural industries. Flexible terms of payment must be instituted for these youngsters. The district and municipal assemblies in these indigenous communities must spearhead and liaise with some foreign donors and entrepreneurship supportive agencies such as Aid to Artisans Ghana and Export Promotions Councils to offer a financial helping hand to these local residents.

Furthermore, technical agencies like the Integrated Technology Transfer Unit (I.T.T.U.), GETRADE Ghana Limited, and GRATIS must offer technical assistance to hone the traditional skills and expertise of production of these local residents and upgrade it to meet the current demands of the market. This technical assistance would aid these local residents endowed with the traditional skills of production to know some simple technologies that can better the finishing and general outlook of the cultural artifacts.

\section{CONCLUSION}

Creative cultural industries are viable income generating employment avenues that can alleviate impoverished communities from their poverty. Thus, various governmental and nongovernmental agencies, as well as the traditional councils in the local communities, must all endeavor to develop these industries that were tirelessly brought into being by the loyal, hardworking and insightful forebears.

The article highlights the great benefits that African societies can gain from the arts and culture practised by the people. African governments, ministries and NGO's in charge of the 
development of art, culture and tourism must ensure the development of this field. Funding in the form of scholarships, research grants and awards must be offered to young scholars, researchers and artists to enhance the study of African art and culture because it is a pinnacle of the social, political and economic development of Africa.

\section{REFERENCES}

Budde, M. L. (2019). The (magic) kingdom of God: christianity and global culture industries. Routledge.

De Beukelaer, C., \& Spence, K. M. (2018). Global Cultural Economy. Routledge.

Dewi, E. W., Nurkamto, J., \& Drajati, N. A. (2019). EXPLORING PEER-ASSESSMENT PRACTICE IN GRADUATE STUDENTS'ACADEMIC WRITING. LLT Journal: A Journal on Language and Language Teaching, 22(1), 58-65.

Gregory, J. J. (2019). Creative Industries and Neighbourhood Change in South African Cities. In The Geography of South Africa (pp. 203-211). Springer, Cham.

Habibi, H. (2018). PROTECTING NATIONAL IDENTITY BASED ON THE VALUE OF NATION LOCAL WISDOM. International Journal of Malay-Nusantara Studies, 1(2), 24-40.

Lewis, P. (2018). Africa: Dilemmas of development and change. Routledge.

Nel, E. L. (2019). Regional and local economic development in South Africa: The experience of the Eastern Cape. Routledge.

Njoh, A. J. (2016). Tradition, culture and development in Africa: Historical lessons for modern development planning. Routledge.

Oyekunle, O. A. (2017). The contribution of creative industries to sustainable urban development in South Africa. African Journal of Science, Technology, Innovation and Development, 9(5), 607616.

Pather, J., \& Boulle, C. (Eds.). (2019). Acts of Transgression: Contemporary Live Art in South Africa. Wits University Press.

Reyes-García, V., Guèze, M., Díaz-Reviriego, I., Duda, R., Fernández-Llamazares, Á., Gallois, S., ... \& Koster, J. (2016). The adaptive nature of culture: a cross-cultural analysis of the returns of local environmental knowledge in three indigenous societies. Current Anthropology, 57(6), 000-000.

Shai, J. (2019, December 27). Diaspora Literature and Stereotypes Concerning Contemporary Art in Africa. https://doi.org/10.31237/osf.io/arjtb

Snowball, J., Collins, A., \& Tarentaal, D. (2017). Transformation and job creation in the cultural and creative industries in South Africa. Cultural Trends, 26(4), 295-309.

Stewart, P. D. S. (2019). Discordant dreams: the spirit of the times in contemporary South Africa. Safundi, 20(1), 100-123. 
Xie, X., Xie, X., \& Martínez-Climent, C. (2019). Identifying the factors determining the entrepreneurial ecosystem of internet cultural industries in emerging economies. International Entrepreneurship and Management Journal, 15(2), 503-522. 